\title{
The Relative Contribution of Brand Love and Country Image towards the Formation of Brand Equity
}

Razie Zilaie

M.A. in Business Administration, Faculty of Management and Economics Tarbiat Modares University, Tehran, Iran; Email: razie.zilaie@modares.ac.ir

\section{Asadollah Kordnaeij}

Associated Professor, Faculty of Management and Economics Tarbiat Modares University, Tehran, Iran; Email: naeij@modares.ac.ir

Parviz Ahmadi

Associated Professor, Faculty of Management and Economics Tarbiat Modares University, Tehran, Iran; Email: ahmadi_p@modares.ac.ir

Doi:10.5901/mjss.2016.v7n2s2p164

\section{Abstract}

The purpose of this study is providing a model to determine the way brand love and country of origin image(Col) affect the formation of brand equity in the automotive industry in Iran. The most important finding of this study was that consumers affection toward a brand and its country of origin has significant influence on consumers 'loyalty and subsequently their loyalty level could affect brand value.Results also showed that there was no significant relation between consumer' cognition of a country characteristics and their attitudinal loyalty. The findings can advance our understandings of brand love and Col phenomena and provide guidance for international marketers and traders to manage country and brand related information more effectively.

Keywords: Brand love, Country image, Affective image, Cognitive image, Brand loyalty, Attitudinal loyalty, Behavioral loyalty, Brand equity

\section{Introduction}

Nowadays in competitive markets, brand is a strategic requirement that helps organizations in order to creating more values for customers and also making sustainable competitive advantages. A brand represents enormous values for a company and is a powerful tool to improve marketing productivity(Aaker, Managing brand equity: Capitalizing on the value of a brand name, 1991). Brand value is commonly called brand equity, which is accrued gradually overtime and can derive from multiple sources (Keller, Conceptualizing, measuring and manging customer-based brand equity, 1993) and it is an added value to products and it may be appeared in the way customers' thinking, feeling and acting towards a brand as the role of brand in prices, market share and company profitability (Kotler \& Keller, 2008).

Maintaining a long term relationship with customers is a challenge for organizations. In recent years, development of the relationship between brand and consumer has been one of the very important and interesting issues for marketing researchers and led to a significant proportion of research devoted to it (e.g. Fournier, 1998; Whang et al., 2004; Carroll and Ahuvia, 2006; Albert, Merunka and Valette-Florence, 2008). Among these relationships, brand love represents the highest level of relationship between consumers and brand. Though there are number of studies about brand love, there is still a lack of research, analyzing how to use consumers emotions in value creation in pursuance of higher brand equity. How to use the feeling of love to make consumer loyal to a specific brand and then translate those emotions in brand value? For now, these questions are not answered in a commonly accepted and ambiguous way. In contrast with love, the concept of country of origin is well recognized for its significance to long term business relationships. According to Jin and et al. (2015), differences in cultural, political and economic factors have made it difficult for multi-national enterprises to gain the benefits of a fully integrated global strategy as well as challenging the theories surrounding globalization (Jin, et al., 2015). On the other hand, marketers' success in global markets mostly depends on 
understanding their consumer behaviors. Usually there are several factors that influence jointly consumers' evaluation such as brand and price but according to Keller (2003) besides to these factors, the country and/or geographical location that products come from are related to brand and its associations (Baldauf, Cravens, Diamantopoulos, \& Roth, 2009) and can strongly affect consumer's perception of a product and its brand.However, further research needs to take a close look at the nature of brand love and Col to identify and study their specific modes and the mechanisms through which they affect brand equity. This study claims that condition in a country of origin of a brand that is recognized by consumers (i.e. economical, technological, cultural, social conditions) and their feelings towards that specific country and also consumers 'experience of love in their interaction with product and its brand may be incompletely correlated with brand value. The study considers the potential influence of loyalty situations in buyers as intervening variable between brand love and Col on one side and brand equity on the other side. Numerous numbers of studies worked on Col and brand love and their consequences, but separately and none of them considered these constructs in a model to view their impacts in brand value creation as a whole, and that is what we trying to show in this study.

Questions this study is dealing with are: how should importers and traders consider the issue of country of origin? Does Iranian buyers consider "made in ..." label as a purchase criterion? Assume that Iranian buyers involving the country of origin in their purchasing decision, is it more dependent on public recognition of or their inner feelings towards that particular country? How to use consumers' emotions in value creation in pursuance of higher brand equity. Can consumers' interest and emotions type and direction affect their buying intentions? In the next section we review the literature and state the research hypotheses to test the proposed research questions.

\section{Literature Review}

\subsection{Brand love}

Nowadays the main asset of many businesses is their trade names. For decades, the value of a company were measured based on its real estate, tangible assets and equipment. However, recently, companies have found that the real value of a company, there is in someplace out of its physical framework, in the mind of potential buyers(Kapferer, 2008). Among the most important organization intangible assets, brands have the highest value and success in the market(Karen, 2001; Venkatesh, Azar, \& Fuller, 2008).Aker (1991) considers brand as indicator of great value for the company that serves as a powerful tool to improve the efficiency of marketing (Cai, Zhao, \& He, 2015). He also regarded brand as a symbol that is associated with a large number of intellectual assets and commitments, which aims to identify and distinguish products(Aaker, 1991). Although decades of study of customer attitudes to brands and its effects on customer behavior passed, but in recent years trend of researches have changed toward putting their focus on the consumer passion and love for brand. During the first decade of this century, researchers such as Ahuvia (2005), Carroll and Ahuvia (2006) and Albert and et al. (2008) were studied brand love with more attention. Wang and et al (2004) have shown in their study that consumers can be in a passionate love for brand, which ultimately can lead to romantic love with the brand over a period of time(Whang, Allen, Sahoury, \& Zhang, 2004). According to Sternberg (1986) romantic love includes intimacy, passion and liking(Sternberg, 1986). Carroll and Ahuvia (2006) defined brand love as the degree of passionate emotional attachment a person has for a trade name. Ahuvia (2005) believe that brand love includes passion for the brand, attachment to the brand, brand positive evaluation, positive feeling in reaction to the brand and expressing love for the brand(Carroll \& Ahuvia, 2006). In most studies in brand love field, the definition offered by Carroll and Ahuviais used.Batra et al. (2012) also establishedthat brand love was mostly expressed in a self-oriented manner,whereby consumers "were concerned with what the brand coulddo for them, not what they could do for the brand"(Batra, Ahuvia, \& Bagozzi, 2012).Besides of love, other terms such as emotional attachment and passion also are being used. For example, Thomson et al (2005) have used term emotional attachment in their definition of love; he stated love as follows:" An attachment is an emotional-laden target-specific bond between a person and a specific object" (Thomson, Maclnnis, \& Park, 2005).

Filho, Monteiro and Souki (2010) consider brand love as a driving force to provide loyalty and purchase behavior (Filho, Monteiro, \& Souki, 2010). Carroll and Ahuvia (2006), referring to the concept of brand love and its definition, believe that brand love can affect customer loyalty to the brand(Carroll \& Ahuvia, 2006). Albert and et al (2008) by describing more accurate of the effects of different aspects of brand love on consumers loyalty believe that between two components of brand love (brand enthusiasm and brand fascination), brand fascination component has more positive impact on customer brand loyalty. Chen and Quester (2015) also mentioned that consumer` experience of love and trust are essential for consumer loyalty. From their perspective, consumer love and his trust to brand are two quite distinct objects from each other and consumer love has much stronger effect on the formation of consumer loyalty. Loyal 
attitudes and behavior of consumer are primarily influenced by his/her love to brand(Chen \& Quester, 2015). Although brand love became as an important consumer-brand relationship construct, there is still the lack of sufficient studies about how we can generate love and emotional relationship between customers and a brand and what would be the behavioral consequences of this relation (e.g., consumer loyalty toward brand). For example, brand love may be influenced by brand characteristics such as brand trust, brand identification, (Albert and Merunka, 2013), and may influence other brand-related concepts such as consumer loyalty toward a particular brand, word-of-mouth and etc. (Carroll and Ahuvia, 2006; Batra et al., 2012; Drennan et al., 2015; Chen and Quester, 2015; Anggraeni and Rchmanita, 2015). This study analyzed separately the effect of brand love on the attitudinal and behavioral construct of brand loyalty. Thus, we propose the first two hypotheses of the study:

$\mathrm{H}_{1}$ : Brand love has a significant positive direct effect on brand attitudinal loyalty.

$\mathrm{H}_{2}$ : Brand love has a significant positive direct effect on brand behavioral loyalty.

\subsection{Country of origin image}

Ahmed (2004) believes that country of origin of the product, indicating the place where goods are made or assembled and customer can infer that from the label on the product that says "made in..." In fact, country of origin indicating any label, logo, packaging or advertising campaigns that suggest consumer, to which country this product belongs. For example, consumers identify many well-known brands with particular countries, even if the product being evaluated was not manufactured in the firm's country of domicile. Thus, Toyota, Sony and Honda products are considered to be Japanese; Marks \& Spencer and Body Shop items are British; McDonald`s and KFC are US (Ahmed, et al., 2004). All products and organizations are always influenced by their country of origin(Baker \& Ballington, 2002).

One of the first conceptualizations of the country of origin phenomenon was that of Nagashima (1970). He defined the image that consumer associated with a given country of origin as: "The picture, the reputation, the stereotype that businessmen and consumer attach to products of a specific country. This image is created by such variables as representative products, national characteristics, economic and political background, history and tradition(Nagashima, 1970).

Image is the schema organized in consumers ' minds, which has been proved to influence the attitude formation towards object/events and behavior intention. In this regard, country image is a set of beliefs in relation to a specific country (Yeh, Chen, \& Sher, 2010). Roth and Romeo (1992) has been defined country image as the overall product perception that consumers from in light of the perceived marketing- and production-related superiority and inferiority of the country where the products are from(Roth \& Romeo, 1992).But what does Col practically mean? It is essentially a kind of customer's rationalperception and legitimate judgment about products/brands from the origin country (Wang, Zhou, Mou, \& Zhao, 2014), meaning it reflects the opinions and emotions of consumers and is a direct result of their knowledge and beliefs, regardless of the rightness or wrongness of these knowledge and beliefs about a particular country. Hsieh and Pan (2004) classified definitions of country image into three groups: (1) overall country image that is the total of all descriptive, inferential, and informational beliefs that a consumer has about a particular country, (2) aggregate product country image that is the entire cognitive "feel" associated with a particular country`s product or with the perceived overall quality of the products from that particular country, and (3) specific product country image that is the overall perception consumers form of specific product categories from a particular country(Hsieh \& Pan, 2004). For example, the image most people have of Japan is a top manufacturing country of durable products, or Italy is known as the leader in leather industry. Switzerland is known as a country with high accuracy products as well as Germany has been recognized for being accurate, England for reliable products and Scotland for its traditional products such as textiles, whiskey or its castles(Baker \& Ballington, 2002).Roth and Diamantopoulos believe country image has two dimensions: cognitive and affective. They define country cognition dimension as the general belief about the whole country, including population, economy, politics, culture, and technology. They also consider country affectdimension as the general emotion about the whole country, such as positive or negative(Roth \& Diamantopoulos, 2009).Balabanis et al. (2002) and Verlegh and Steenkamp (1999) also considered cognitive dimension as a cue of product quality and affective dimension as symbolic and emotional value of country of origin to customers.Perhaps the best definition given for country image is the one offered by Lu Wang et al (2012), which refers to both cognitive and emotional image of country. He believes that country image refers to the mental representation of a country and its people, including cognitive believes of the country's economic and technological development stages, as well as the affective evaluations of its social and political systems or standpoints and affective country image refers to consumer affective evaluations (i.e., to like or dislike, be positive or negative) regarding a country and its people(Wang, Li, Barnes, \& Ahn, 2012).

Saydan (2013), quoting Rave et al (2007), states that consumers country of origin beliefs in relation to a familiar 
product category transferred to new product offered from the same country. His research shows that country image has positive influence on brand loyalty and overall brand equity (Saydan, 2013). Panda and Misra (2014) found that the country of image has both direct and indirect relationship with brand equity and in this linkage brand loyalty acts as mediator. Relationship between Col and brand was found to be positive which implies that a good Col will lead to an improved customer loyalty (Panda \& Misra, 2014). In the present study the effect of each dimensions of Col (cognitive and affective) on both components of brand loyalty (attitudinal and behavioral) are analyzed. Based on the above definitions and the suggested relationship of Col and brand loyalty in the literature, the following hypotheses are formulated.

$\mathrm{H}_{3}$ : Cognitive country image has a significant direct influence on attitudinal brand loyalty.

$\mathrm{H}_{4}$ : Cognitive countryimage has a significant direct influence on behavioral brand loyalty.

$\mathrm{H}_{5}$ : Affective country image has a significant effect on attitudinal brand loyalty.

$\mathrm{H}_{6}$ : Affective countryimage has a significant effect on behavioral brand loyalty.

\subsection{Brand loyalty}

Oliver (1999) defines brand loyalty as"a deeply held commitment to rebuy or repatronize a preferred product/service consistently in the future, thereby causing repetitive same brand or same brand set purchasing, despite situational influences and marketing efforts having the potential to cause switching behavior". This definition considers both attitude and behavior aspects of brand loyalty. Generally brand loyalty has been considered either an attitude or behavior. From an attitudinal perspective, brand loyalty is "the tendency to be loyal to a focal brand as demonstrated by the intention to buy it as a primary choice" (Oliver, Satisfaction: A brhavioral perspective on the consumer, 1997) and it relates to the degree of dispositional commitment towards the brand(Chaudhuri \& Holbrook, 2001).From behavioral perspective, brand loyalty is the degree to which a buying unit such as a household concentrates its purchases over time on a particular brand within a product category and relates to repeat purchases (Dick \&Basu, 1994; Amine, 1998; Chaudhuri\& Holbrook, 2001; Chiu et al, 2013).Both components explain the formation of brand loyalty. Attitudinal component indicates that loyalty formation stems from a positive bond or commitment between consumer and brand. This attitude arises from the coincidence between the brand attributes and the consumer's preferences. Behavioral component indicates that loyalty formation is explained by the consumer's prior purchases which result in a certain purchase habit (Dick \& Basu, 1994).

Many of studies considered brand loyalty as the most important variable that influence brand equity. Researchers such as Atilgan et al (2005), Konecnik and Gartner (2007) and Panda and Misra (2014) in separate research have stressed on the role of brand loyalty in affecting brand equity and the existence of a significant relationship between them. Hence the following hypothesis of the relationship between brand loyalty components and brand equity are proposed:

$\mathrm{H}_{7}$ : Brand attitudinal loyalty has a significant positive direct effect on brand equity.

$\mathrm{H}_{8}$ : Brand behavioral loyalty has a significant positive direct effect on brand equity.

\subsection{Brand equity}

There is no comprehensive and acceptable definition for brand equity. Various people and institutions, depending on their field research and intended purpose have offered definitions for brand equity (e.g. Srivastava and Shocker, 1991; Keller, 1993; Aaker 1996; Kotler and Keller, 2008) .However, several common characteristics can be found among these definitions. Since the introduction of "brand equity", growing attention appeared among researchers and marketing professionals; Definitions such as added value by brand name (Cobb-Walgren, Ruble, \& Donthu, 1995); growing benefit (Kamakura \& Russell, 1993); the difference between the overall brand preference and some preferred features based on targeted measured levels of feature (Srivivasan \& Park, 1994). According to the Farquhar definition of brand equity (1989), brand equity is the added value that a brand gives to a product (Farquhar, 1989). Aaker (1991) defined brand equity as a set of brand assets and liabilities linked to a brand name and symbol, which add or subtract from the value provided by a product or service. In his model, brand equity has four dimensions: brand loyalty. Brand awareness, brand associations and perceived quality, each are providing value to a firm in numerous ways (Aaker, Managing brand equity: Capitalizing on the value of a brand name, 1991). Keller (2003) argues that high brand equity provides more differentiation, higher brand knowledge and better consumer response, leading to superior brand performance(Keller, Strategic brand management: Building, measuring, and managing brand equity, 2003). While seeking for a brand success in the market, it's important to understand the consumer's, as an activepartner's, role in brand value creation.Both the consumer andthe company play different roles in value creation.Brand advantages are understood as brand value forcustomer(Kuvykaite \& Piligrimiene, 2014). 

this study.

The hypotheses explained above are presented in the framework of research model, shown in figure 1 below for

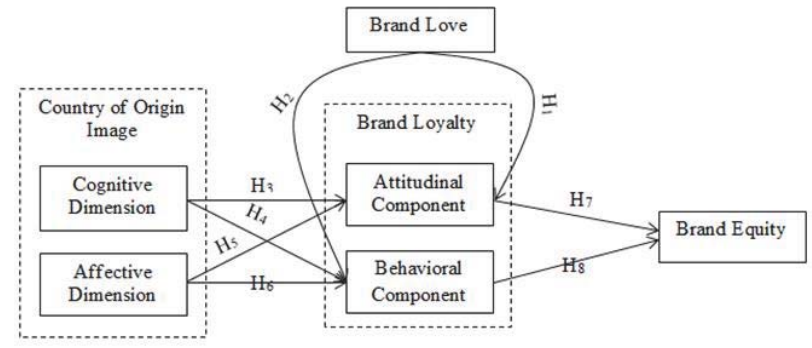

Figure 1. Research model of study

\section{Methodology}

\subsection{Site selection}

Although literature on brand love and country of origin and brand equity is abundant, data on the effects of these relationships are scarce for Iranian consumers. This case study is based on Iranian consumers ' perceptions towards specific foreign automobiles. Iranian people have a tendency to foreign goods. The results of a survey of Iranian urban population taste showed that $60 \%$ of Iranian citizens cater their needful from foreign goods. Also surveys among residents of seven biggest cities in Iran revealed that only $40 \%$ of residents in different education and age groups prefer to buy their country made products(IRIB Research, 2012). Among the variety of imported products, increasing demand for automobiles has also been impressive. The automobile industry is seen as Iran's biggest non-oil sector. It accounts for nearly 10 percent of the country's gross domestic product (GDP). According to the official statistics of Customs Administration of Iran from 2006 the import of cars is rising. According to this report only during last Persian calendar year Iran imported 102,000 cars worth 2.128 billion dollars; that shows a 31\% year-on-year increase. In April 2015, a member of the Iranian auto parts association said 60 percent of auto spare parts in the Iranian market have been imported from foreign countries(Press TV, 2015). This shows the attractiveness of the automotive market for merchants and importer in Iran. On the other hand, with the increasing the currency price and considering that car is an expensive commodity than other imported products and consumers impose in buying it high accuracy and sensitivity; the risk of selling this product is high for importers. Therefore, it is important to investigate on constructs that affect brand equity, particularly in automotive sector.

\subsection{Sampling and data collection}

In accordance with the above literature, the aim of this research is to analyze the influence of brand love and Col on brand equity. This research in respect of its goal is applicative and in respect of its data gathering method is descriptivecorrelation type from the structural equation modelling of branch. A research framework was designed to test this study hypothesized in the automotive industry in Iran. For this purpose particularly Toyota, Hyundai and Peugeot brands and their home countries (Japan, South Korea and France) targeted. The research was undertaken with consumers using these car brands, where car owners were randomly approached and asked at participate in the study. Data was collected at several locations in Tehran, the capital of Iran.

To determine the sample size Cochran formula for an infinite population were used. In total 430 questionnaires were distributed, however 400 questionnaires were fully completed and were used for the final analysis. A profile of the sample of respondents is presented in table 1.

Table 1: Biographical Variables of the Participants

\begin{tabular}{|l|c|c|c|}
\hline Variables & Demographic Categories & Frequency & Percent \\
\hline \multirow{2}{*}{ Gender } & Male & 267 & 66.8 \\
\cline { 2 - 4 } & Female & 133 & 33.3 \\
\hline
\end{tabular}




\begin{tabular}{|l|c|c|c|}
\hline \multirow{4}{*}{ Age Group } & Under 30 & 73 & 18.3 \\
\cline { 2 - 4 } & $30-39$ & 164 & 41.0 \\
\cline { 2 - 4 } & $40-49$ & 137 & 34.3 \\
\cline { 2 - 4 } & Over 50 & 26 & 6.5 \\
\hline \multirow{4}{*}{ Marital Status } & Married & 279 & 69.8 \\
\cline { 2 - 4 } & Single & 121 & 30.3 \\
\cline { 2 - 4 } & Under Diploma & 15 & 3.8 \\
\cline { 2 - 4 } & Diploma & 108 & 27.0 \\
\cline { 2 - 4 } & Bachelor & 87 & 39.0 \\
\cline { 2 - 4 } & Master & 34 & 21.8 \\
\cline { 2 - 4 } & Ph.D. & & 8.5 \\
\hline
\end{tabular}

\subsection{Measures}

In this study, standard questionnaires were used as the main data gathering instrument. Appropriate scales for the focal constructs were identified after a careful review of the pertinent literature, which in previous research have been generally found to be valid and reliable (Table 2). Then, through interview with experts and university professors, questionnaire was designed and developed to evaluate variables. This questionnaire has been prepared in two sections. The first section, measuring demographic data of respondents and the second section contains the main questions related to the research objectives. To verify its reliability and validity status, it was pre-tested with a group of car owners in Tehran.

Table 2: Resourced used to design the questionnaire

\begin{tabular}{|l|l|c|l|}
\hline Variable & Questions & Reference(s) \\
\hline Brand love & $1-10$ & Barbara A. Carroll \& Aaron C. Ahuvia (2006); Noel Albert et al (2009) \\
\hline \multirow{2}{*}{ Country of origin image } & Cognitive image & $1-8$ & Cheng Lu Wang \& et. (2012); NorjayaMohdYasin\& et al. (2012) \\
\cline { 2 - 4 } & Affective image & $9-15$ & Cheng Lu Wang \& et. (2012); NorjayaMohdYasin\& et al. (2012) \\
\hline \multirow{2}{*}{ Brand loyalty } & Behavioral loyalty & $1-4$ & Sharyn Rundle-Thiele (2005); Athanasios Krystallis\&PolymerosChrysochou (2014) \\
\cline { 2 - 4 } & Attitudinal loyalty & $5-8$ & Sharyn Rundle-Thiele (2005); Athanasios Krystallis\&PolymerosChrysochou (2014 \\
\hline Brand equity & $1-13$ & Edo Rajh (2002) \\
\hline
\end{tabular}

Since the sampling method used in this research is cluster sampling, therefore for each of the identified clusters (Hyundai-South Korea, Toyota-Japan and Peugeot-France) separated questionnaires were designed and responded. For all variables the 5-point Likert scale were used.

Since this study used the standard questionnaires, therefore, research instrument has the needed validity, however, to ensure of content validity, the experts and professionals ideas in both field of marketing and research were used. Also, through the SmartPLS program convergent validity was determined for each variable. As seen in Table 3, the validity of each variable is more than 0.5 , it means all variables have high convergence validity, thus research tool has appropriate validity.

In orderto determine scale reliability, composite reliability and PLS program were used. As seen in Table 4, composite reliability for all constructs is more than 0.7 that indicating a reasonable level of internal consistency and reliability among the items.

Table 3: Convergence validity of research variables

\begin{tabular}{|l|l|}
\hline Variable & $\mathrm{AVE}^{1}$ \\
\hline Brand love & 0.730 \\
\hline Affective country of origin image & 0.634 \\
\hline Cognitive country of origin image & 0.525 \\
\hline Behavioral brand loyalty & 0.636 \\
\hline Attitudinal brand loyalty & 0.664 \\
\hline Brand equity & 0.567 \\
\hline
\end{tabular}

Table 4: Composite reliability of research variables 


\begin{tabular}{|l|c|c|}
\hline Variable & Number of Questions & Composite Reliability \\
\hline Brand love & 10 & 0.964 \\
\hline Affective country of origin image & 7 & 0.920 \\
\hline Cognitive country of origin image & 8 & 0.879 \\
\hline Behavioral brand loyalty & 4 & 0.838 \\
\hline Attitudinal brand loyalty & 4 & 0.868 \\
\hline Brand equity & 13 & 0.964 \\
\hline
\end{tabular}

\subsection{Research analysis and findings}

This part of the manuscript illustrates the findings of the study and the testing of our concept that was earlier proposed. In order to do this, we analyzed the data using structural equation modeling (SEM). SEM was considered highly appropriate for this study as relations between the constructs could be considered simultaneously and tested holistically.

To ensure the distribution of constructs, Kolmogorov-Smirnov test was used. According to outputs of this test, obtained significant levels for all constructs are less than 0.5 and so the hypothesis of normal distribution cannot be confirmed. As a result, to assess the correlation between variables, Spearman correlation test in SPSS program was used and the following two sub-hypothesis are applied.

$H_{0}: \rho=0$ : The correlation coefficient between the two variables is zero and there is no significant relation between the two variables.

$H_{1}: \rho \neq 0$ : The correlation coefficient between the two variables is non-zero and there is a significant relation between the two variables.

The result of the correlation coefficient analysis for all variables is presented in Table 5.

Table 5: Correlation matrix (spearman correlation coefficient) of research variables

\begin{tabular}{|c|c|c|c|c|c|c|c|}
\hline \multicolumn{2}{|l|}{ Variable } & (1) & $(2)$ & (3) & (4) & (5) & (6) \\
\hline (1) Affective country of origin image & SpeCor Sig & 1 & & & & & \\
\hline (2) Cognitive country of origin image & SpeCor Sig & $\begin{array}{l}0.540 \\
0.000\end{array}$ & 1 & & & & \\
\hline (3) Behavioral brand loyalty & SpeCor Sig & $\begin{array}{l}0.644 \\
0.000\end{array}$ & $\begin{array}{l}0.461 \\
0.000 \\
\end{array}$ & 1 & & & \\
\hline (4) Attitudinal brand loyalty & SpeCor Sig & $\begin{array}{l}0.560 \\
0.000\end{array}$ & $\begin{array}{l}0.490 \\
0.000\end{array}$ & $\begin{array}{l}0.640 \\
0.000\end{array}$ & 1 & & \\
\hline (5) Brand love & SpeCor Sig & $\begin{array}{l}0.617 \\
0.000\end{array}$ & $\begin{array}{l}0.523 \\
0.000 \\
\end{array}$ & $\begin{array}{l}0.736 \\
0.000 \\
\end{array}$ & $\begin{array}{l}0.622 \\
0.000 \\
\end{array}$ & 1 & \\
\hline (6) Brand equity & SpeCor Sig & $\begin{array}{l}0.583 \\
0.000\end{array}$ & $\begin{array}{l}0.502 \\
0.000\end{array}$ & $\begin{array}{l}0.777 \\
0.000\end{array}$ & $\begin{array}{l}0.598 \\
0.000\end{array}$ & $\begin{array}{l}0.763 \\
0.000\end{array}$ & 1 \\
\hline SpeCor: Spearman Correlation & ig. (2-tailed) & & & & & & \\
\hline
\end{tabular}

As the result of correlation test shows that significant value for all relationships between variables is less than standard level ( $\alpha=0.5$ ), thus correlation between variables is confirmed.

The theoretical accuracy of the model has been searched by using structural equation modeling (SEM) and PLS program. In order to determine the validity if the hypothesized paths, the statistical significance of all structural parameter estimates was examined. The structural parameters and the hypothesis-testing results are shown in Table 6.

Table 6: Path coefficients and t-values for research model hypotheses

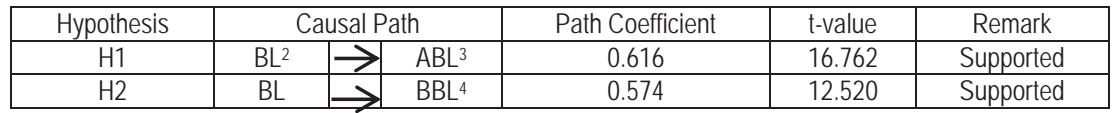

\footnotetext{
2 Brand love

${ }^{3}$ Attitudinal brand loyalty

${ }^{4}$ Behavioral brand loyalty
} 


\begin{tabular}{|c|c|c|c|c|c|c|}
\hline $\mathrm{H} 3$ & $\mathrm{CCl}^{5}$ & $\longrightarrow$ & $\mathrm{ABL}$ & 0.057 & 1.270 & Rejected \\
\hline $\mathrm{H} 4$ & $\mathrm{CCl}$ & $\longrightarrow$ & $\mathrm{BBL}$ & 0.150 & 3.004 & Supported \\
\hline $\mathrm{H} 5$ & $\mathrm{ACl}$ & $\longrightarrow$ & $\mathrm{ABL}$ & 0.254 & 6.292 & Supported \\
\hline $\mathrm{H} 6$ & $\mathrm{ACl}$ & $\longrightarrow$ & $\mathrm{BBL}$ & 0.174 & 3.471 & Supported \\
\hline $\mathrm{H} 7$ & $\mathrm{ABL}$ & $\longrightarrow$ & $\mathrm{BE}^{7}$ & 0.634 & 13.040 & Supported \\
\hline $\mathrm{H} 8$ & $\mathrm{BBL}$ & $\longrightarrow$ & $\mathrm{BE}$ & 0.251 & 4.935 & Supported \\
\hline
\end{tabular}

Table 6 showedthe path confidence for all research hypotheses paths were significant $(t>1.96)$ and all of them were verified except $\mathrm{H} 3$. Based on the output of table 6 , $\mathrm{t}$-value for $\mathrm{H} 3$ was 1.270 and it is less than the accepted level ( $\mathrm{t}>1.96)$; therefore, $\mathrm{H} 3$ that predicted the relationship between cognitive Col and attitudinal brand loyalty was statistically rejected. The subjects ' perception of country image for each three countries and their consideration of three other constructs (brand love, brand loyalty and brand equity) for each car brands in questions were examined using post hoc LSD with multiple comparisons (see Table 7 and Table 8). The findings reveal that both cognitive and affective country images associated with France appears to be the lowest among the three countries. However, the Japan scored the highest in terms of both cognitive and affective country images. Also it can be seen that from respondents view,the intensity for both attitudinal and behavioral components of brand loyalty, brand love and brand equity for these triple car brands are different.

Table 7: Results of post hoc LSD test for country image dimensions comparison in triple countries

\begin{tabular}{|c|c|c|c|c|c|c|c|}
\hline Variable & \multicolumn{2}{|c|}{ Countries Comparison } & Sig & Lower Limit & Upper Limit & Result & Prioritization \\
\hline \multirow[t]{3}{*}{ Affective country image } & Japan & Korea & 0.000 & 0.202 & 0.588 & Different & \multirow{3}{*}{ Japan $>$ Korea $\approx$ France } \\
\hline & Japan & France & 0.000 & 0.392 & 0.777 & Different & \\
\hline & Korea & France & 0.000 & -0.003 & 0.382 & Similar & \\
\hline \multirow[t]{3}{*}{ Cognitive country image } & Japan & Korea & 0.000 & 0.303 & 0.531 & Different & \multirow{3}{*}{ Japan>Korea>France } \\
\hline & Japan & France & 0.000 & 0.469 & 0.696 & Different & \\
\hline & Korea & France & 0.004 & 0.052 & 0.279 & Different & \\
\hline
\end{tabular}

Table 8: Results of post hoc LSD test for brand loyalty components, brand love and brand equity comparison in triple brands

\begin{tabular}{|c|c|c|c|c|c|c|c|}
\hline \multirow{4}{*}{\begin{tabular}{|l} 
Variable \\
Attitudinal brand loyalty \\
\end{tabular}} & \multicolumn{2}{|c|}{ Brand Comparison } & \multirow{2}{*}{\begin{tabular}{|c|} 
Sig \\
0.028 \\
\end{tabular}} & \multirow{2}{*}{\begin{tabular}{|c|} 
Lower Limit \\
0.024
\end{tabular}} & \multirow{2}{*}{$\frac{\text { Upper Limit }}{0.428}$} & \multirow{2}{*}{\begin{tabular}{|c|} 
Result \\
Different \\
\end{tabular}} & \multirow{2}{*}{ Prioritization } \\
\hline & Toyota & Hyundai & & & & & \\
\hline & \begin{tabular}{|l|} 
Toyota \\
\end{tabular} & Peugeot & 0.000 & 0.395 & 0.797 & Different & \multirow{2}{*}{ Toyota>Hyundai>Peugeot } \\
\hline & Hyundai & Peugeot & 0.000 & 0.170 & 0.572 & Different & \\
\hline \multirow[t]{3}{*}{ Behavioral brand loyalty } & Toyota & Hyundai & 0.985 & -0.163 & 0.160 & Different & \multirow{3}{*}{ Toyota $\approx$ Hyundai>Peugeo } \\
\hline & \begin{tabular}{|l|} 
Toyota \\
\end{tabular} & Peugeot & 0.000 & 0.338 & 0.660 & Different & \\
\hline & Hyundai & Peugeot & 0.000 & 0.339 & 0.662 & Different & \\
\hline \multirow[t]{3}{*}{ Brand love } & Toyota & Hyundai & 0.124 & -0.045 & 0.373 & Similar & \multirow{3}{*}{ Toyota $\approx$ Hyundai>Peugeot } \\
\hline & Toyota & Peugeot & 0.000 & 0.546 & 0.963 & Different & \\
\hline & Hyundai & Peugeot & 0.000 & 0.382 & 0.799 & Different & \\
\hline \multirow[t]{3}{*}{ Brand equity } & Toyota & Hyundai & 0.011 & 0.053 & 0.405 & Different & \multirow{3}{*}{ Toyota> Hyundai>Peugeot } \\
\hline & Toyota & Peugeot & 0.000 & 0.330 & 0.681 & Different & \\
\hline & Hyundai & Peugeot & 0.002 & 0.101 & 0.453 & Different & \\
\hline
\end{tabular}

\section{Discussion and Conclusion}

This study deals with the possible effect of the "country of origin image" and "brand love", with regard to the role of brand loyalty as a mediator variable, which is potentially important psychological factor on the brand value.

The consumers feeling towards a particular brand and country name effects on their purchase process, positively or negatively, could detract decision-making process from rational level (quality, price, packaging and etc.). Therefore, in case of existing of such effects, this study try to show that firms shall not explain their market performance only with

\footnotetext{
${ }^{5}$ Cognitive country image

${ }^{6}$ Affective country image

${ }^{7}$ Brand equity
} 
rational measuring fields and their marketing strategies. Results of this study showed that although the consumers' cognition of manufacturing country affects their purchase behavior and biases but their feelings for this country and their interest or hate for a specific brandcould affect consumers' loyalty and as a result influence brand value as well.

The research result has shown that the evaluations consumers have for Col can affect their evaluating process of brand in many different ways. Also their evaluations could directly affect brand loyalty and indirectly brand equity. Therefore, marketers should consider that although consumers recognize manufacturing country as a nation with skills, technology and creativity, but their feelings for this country can play a vital role in the orientation of their loyalty to products and brands of the country. This is linked to findings of researchers such as Roth and Diamantopoulos (2009), Wang et al (2012) and Alvarez and Campo (2014). They believe countries are not such well-known or are involved in crisis such as internal war;individuals' affection toward those countries more than anything can affect their decision about keep buying products and brands origin from these countries. Therefore, knowing elements can influence customers' emotions to country of origin such as historical background and current relationships between host and origin countries will become very important.

Considering Toyota and Hyundai brands as the main actors in the automotive market in Iran, it can be said, regardless of the importance of using the right marketing strategy for brands, manufacturer name can increase effectiveness of these strategies. It can be also seen in the results of the views analysis that Toyota and Hyundai besides having strong country images, they're also using marketing strategies. Depending on consumer evaluations about the country image, it is clear that the struggle between a brand with double-resourced competitive power and a brand with singular-resourced competitive power is not a balances and fair struggle and the former will has much higher competitive power. Researchers such as Alvarez and Campo (2014), Kim et al (2008), Bahaee and Pisanie (2009) also believe a country has the higher utility in consumer mind, the more positive impact on the consumer perception of brand will has.

Given the obvious importance of Col effect on brand loyalty and brand equity, directly and indirectly and guaranteed profitability of positive image for company, companies need to invest in their brand awareness programs such as advertising, publicity, and branding programs and thus improving their brand Col.

As this study model suggests customers loyalty to a brand besides the image of country of origin, is depended on customers love to the brand; if host country has a negative attitude about origin country, firms should strive to ensure the legitimacy and desirability of their products through using innovations in technology and management control techniques, enhancing product quality, services and after-sales services and brand communications. Albert et al (2008), Fournier and Mike (1999) and Filho et al (2010) had admitted that the amount and intensity of an individual love to given brand can affect the orientation of his/her attitude and his loyalty to the brand. Therefore, for industries such as automotive, one of the best measures to compensate the lack of a favorable country image is trying to improve brand and product essence characteristics and establish long-term relationships with client.

Based on the findings of this study, although a country like France hold a large proportion of Iranian cars market share, but consumers love for this brand is less than what expected and this shows negative feelings towards Peugeot. So it is recommended that firms identify type and intensity of their consumers brand love and classify them in terms of their tolerance and response to deficiencies of product; and decide in accordance with each group what activities shouldtake to reinforce positive passions and weaken negative passions. Thomson et al (2005), Carroll and Ahuvia (2006), Albert et al (2008) and Filho et al (2010) also indicated that marketers can use individuals brand love as the driving force of consumer' loyalty and purchasing behavior. In general, companies should be aware of this when focus on what constructs? If brand is known among consumers and has a good position but in contrast country of origin doesn't have a favorable image, companies positioning must be based on their brand love not country image. This is related to this study ' hypnoses about the impact of brand love on brand loyalty and the influence of brand equity. In contrast, when country of origin has a powerful and positive image in host country but product brand doesn't have such a favorable positionin consumers' mind, the correct strategy is emphasis on country image and highlights that in the consumers' eyes. This could be because of using of country image as the consumer stereotype to identify product quality and brand which they're not familiar with.

Results of this study offer marketers to focus on emotional branding strategies. For instance they should design such an attractive and passionate logo by which customers get attracted to the brand. advertising should contain more affective and emotional themes in order to stimulate consumers love the product's brand. It is recommended that managers in market segmentation had better put their emphasis on those parts in which consumers highly involved to the product. Marketers also should try to better design a kind of brand image which is fit with target market characteristics in the best way.

As can be seen in the research model, brand loyalty affects brand equity directly. Aker (1991), Chaudhuri (1997), Oliver (1999), Keller (2003), Bowen and Shoemaker (2003) have found that by changes in the intensity of loyalty to a 
particular brand, the brand value will change too. In fact, Aker believes if customers keep buying a particular brand, whereas competitors offer better features, prices and facilities, the brand has a significant value.Therefore, various marketing activities, such as marketing communications, sales promotion, publicity and effective community participation can play a key role in increasing customer loyalty. Company emphases on creation and promotion of loyalty because it is time consuming; it must be one of the company's long-termgoals. Thus, considering the principles of consumer relationship management can guarantee the survival of consumers and their loyalty to the company products.

\section{Limitations and Future Research}

Aswith all empiricalwork this study is notwithout limitations.First, although asking questions based on specific brands can elicit a concrete, but using only particular brands in the sample may provide limited generalization of the study result. Therefore, future research can examine whether our model can be generalize to all industry, especially in service industry, and product types.

Second, in this study we examined only the impacts of brand love and Col on consumers' perceived value of brand. Thus, future research might test the effect of other important variables on brand equity such as ethnicity and cultural effects.

Third, this study utilized Iranian customers`comments about France, Japanese and South Korean cars to examine the model. Although we found some differences on customers`attitudes toward those countries, we didn 't further explore that how host country's institutional characteristics exert influence on its consumers 'perceptions of foreign products due to it is beyond the focus of this study. Therefore, future studies may want to examine these kinds of questions.

\section{References}

Aaker, D. A. (1991). Managing brand equity: Capitalizing on the value of a brand name. New York: The Free Press.

Aaker, D. A. (1996). Measuring brand equity across products and markets. California Management Review, 38(3), 102-120.

Ahmed, Z. U., Johnson, J. P., Yang, X., Chen, K. F., Han, S. T., \& Lim, C. B. (2004). Does country of origin matter for low- involvement products? International Marketing Review, 21(1), 102-120.

Albert, N., \& Merunka, D. (2013). The Role of Brand Love in Consumer-Brand Relationship. Journal of Consumer Marketing, 30(3), 258266.

Albert, N., Merunka, D., \& Valette-Florence, P. (2009). The feeling of love toward a brand: Concept and measurment. Advances in Consumer Research, 36, 300-307.

Amine, A. (1998). Consumers` True Brand Loyalty: The Central Role of Commitment. Journal of Strategic Marketing, 6(4), 305-319.

Anggraeni, A., \& Rachmanita. (2015). Effects of Brand Love, Personality and Image on Word of Mouth; the Case of Local Fashion Brands among Young Counsumers. 2nd Global Conference on Business and Social Science (pp. 442-447). Bali, Indonesia: Procedia-Social and Behavioral Sciences.

Atilgan, E., Aksoy, S., \& Akinci, S. (2005). Determinants of The Brand Equity: A Verification Approach in The Beverage Industry Turkey. Marketing Intelligence \& Planning, 23(3), 237-248.

Baker, M. J., \& Ballington, L. (2002). Country of origin as a source of competitive advantage. Journal of Strategic Marketing, 10(2), 157168.

Balabanis, G., Mueller, R., \& Melewar, T. (2002). The Human Values`Lenses of Country of Origin Images. International Marketing Review, 19(6), 582-610.

Baldauf, A., Cravens, K., Diamantopoulos, A., \& Roth, K. (2009). The Impact of Product-Country Image and Marketing Efforts on Retailer-Perceived Brand Equity: An Empirical Analysis. journal of retailing, 2009(85), 437-452.

Batra, R., Ahuvia, A., \& Bagozzi, R. P. (2012). Brand Love. Journal of Marketing, 76(2), 1-16.

Bowen, J. T., \& Shoemaker, S. (2003). Loyalty: A strategic commitment. Cornell Hospitality Quarterly, 44(5-6), 31-46.

Cai, Y., Zhao, G., \& He, J. (2015). Influences of two modes of intergenerational communication on brand equity. Journal of Business Research, 68, 553-560.

Carroll, B., \& Ahuvia, A. C. (2006). Some antecedents and outcomes of brand love. Marketing Letters, 17, 79-89.

Chaudhuri, A. (1999). Does brand loyalty mediate brand equity outcomes? Journal of Marketing Theory and Practice, 7(2), 81-93.

Chaudhuri, A., \& Holbrook, M. B. (2001). The Chain of Effects from Brand Trust and Brand Affect to Brand Performance: The Role of Brand Loyalty. Journal of Marketing, 65(2), 81-93.

Chen, S.-C., \& Quester, P. G. (2015). The relative contribution of love and trust towards customer loyalty. Australasian Marketing Journal, 23, 13-18.

Chiu, C.-M., Cheng, H.-L., Huang, H.-Y., \& Chen, C.-F. (2013). Exploring Individuals` subjective Well-Being and Loyalty Social Network Sites from The Perspective of Network Extenalities: The Facebook Case. International Journal of Information Management, 33(3), 539-552.

Cobb-Walgren, C. J., Ruble, C. A., \& Donthu, N. (1995). Brand equity, bran prefrences, and brand purchase intent. Journal of Advertising, 24(3), 25-40. 
Dick, A. S., \& Basu, K. (1994). Customer loyalty: Toward an integrated conceptual framework. Journal of the Acadamy of Marketing Science, 22(2), 99-113.

Drennan, J., Bianchi, C., Cacho-Elizondo, S., Louriero, S., Guibert, N., \& Proud, W. (2015). Examining The Role of Wine Brand Love on Brand Loyalty: A Multi-Country Comparison. International Journal of Hospitality Management, 49, 47-55.

Farquhar, P. H. (1989). Managing brand equity. Journal of Marketing Research, 1(9), 24-33.

Filho, C. G., Monteiro, P. R., \& Souki, G. Q. (2010). The impact of brand love, brand equity in the consumer`s loyalty and the customer's purchase intentions: The development and testing of alternative models in the automative sector. Encontro da ANPAD, 1-17.

Hsieh, M.-H., \& Pan, S.-L. (2004). Product-,corporate-, and country- image dimensions and purchase behavior: A multicountry analysis. Journal of the Academy of Marketing Science, 32(3), 251-270.

IRIB Research. (2012, December 15). IRIB Research. Retrieved from IRIB Research Web site: http://www.iribresearch.ir/viewnews. asp?id=3279

Jin, Z., Lynch, R., Attia, S., Chansarkar, B., Gulsoy, T., Lapoule, P., . . . Ungerer, M. (2015). The relationship between consumer ethnocentrism, cosmopolitanism and product country image among younger generation consumers: The moderating role of country development status. International Business Review, 24, 380-393.

Kamakura, W. A., \& Russell, G. J. (1993). Measuring brand value with scanner data. Journal of Reasearch in Marketing, $10(1)$, 9-21.

Kapferer, J. N. (2008). The new strategic brand management: Creating and sustaining brand equity long term (4th ed.). London: Kogan Page.

Karen, D. V. (2001). Managing brand overtime. Business World.

Keller, K. L. (1993). Conceptualizing, measuring and manging customer-based brand equity. The Journal of Marketing, 57(1), 1-22.

Keller, K. L. (2003). Strategic brand management: Building, measuring, and managing brand equity (2 ed.). Upper Saddle River, New Jersey: Prentice Hall.

Konecnik, M., \& Gartner, W. C. (2007). Customer-Based Brand Equity for a Destination. Annals of Tourism Research, 34(2), $400-421$.

Kotler, P., \& Keller, K. L. (2008). Marketing management. New Delhi: Printic Hall.

Krystallis, A., \& Chrysochou, P. (2014). The effects of service brand dimensions on brand loyalty. Journal of Retailing and Consumer Services, 21, 139-147.

Kuvykaite, R., \& Piligrimiene, Z. (2014). Consumer engagement into brand equity creation. Procedia - Social and Behavioral Sciences, 156, 479-483.

Nagashima, A. (1970). A comparison of Japanese and U.S. attitudes toward foreign products. Journal of Marketing, 34(1), 68-74.

Oliver, R. L. (1997). Satisfaction: A brhavioral perspective on the consumer. NewYork: McGraw Hill.

Oliver, R. L. (1999). Whence consumer loyalty? Journal of Marketing, 63, 33-44.

Panda, R. K., \& Misra, S. (2014). Impact of Country-of-Origin Image on Brand Equity: A Study on Durable Products in India. 10th International Strategic Management Conference (pp. 494-499). Procedia-Social and Behavioral Sciences .

Papadopoulos, N., \& Heslop, L. A. (1993). Product- Country image:Impact and role in international marketing. New York: The Haworth Press.

Press TV. (2015, April 11). presstv.ir. Retrieved April 11, 2015, from Press Tv Web site: http://www.presstv.ir/Detail/2015/04/11/405708/ Iran-car-imports-up-by-31

Rajh, E. (2002). Development of a scale for measuring customer-based brand equity. Ekonomski Pregled, 53, 770-781.

Roth, K., \& Diamantopoulos, A. (2009). Advancing the country image construct. Journal of Business Research, 63(4), 726-740.

Roth, M. S., \& Romeo, J. B. (1992). Matching product and country image perceptions: A framework for managing country - of - origin effects. Journal of International Business, 23(3), 477-497.

Rundle-Thiele, S. (2005). Elaborating customer loyalty: Exploring loyalty to wine retailers. Journal of Retailing and Consumer Services, $12,333-344$

Saydan, R. (2013). Relationship between country image and brand equity: An empirical evidence in england market. International Journal of Business and Social Science, 4(3), 78-88.

Srivastava, R. K., \& Shocker, A. D. (1991). Brand equity: A perspective on its meaning and measurement. Marketing Science Institute $(\mathrm{MSI})$.

Srivivasan, S. V., \& Park, C. S. (1994). A survey-based method for measuring and undrestanding brand equity and its exendability. Journal of Marketing Research, 31(2), 271-288.

Sternberg, R. J. (1986). A triangular theory of love. Psychological Review, 93(2), 119-135.

Thompson, F. M., Newman, A., \& Liu, M. (2014). The moderating effect of individual level collectivist values on brand loyalty. Journal of Business Research, 67, 2437-2446.

Thomson, M., MacInnis, D. J., \& Park, W. C. (2005). The ties that bind: Measuring the strength of consumers` emotional attachments to brands. Journal of Consumer Psychology, 15(1), 77-91.

Venkatesh, S., Azar, P., \& Fuller, M. (2008). Practice priza paper- BRAND*EQT: A multicategory brand equity model and its application at allstate. Marketing Science, 27(4), 84-567.

Verlegh, p. W., \& Steenkamp, J.-B. E. (1999). A review and meta-analysis of country-of-origin research. Journal of Economic Psychology, 20, 521-546.

Wang, C. L., Li, D., Barnes, B. R., \& Ahn, J. (2012). Country image, product image and consumer purchase intention: Evidence from an emerging economy. International Business Review, 21, 1041-1051.

Wang, T., Zhou, L., Mou, Y., \& Zhao, J. (2014). Study of Country-of-Origin Image from Legitimacy Theory Perspective: Evidence from 
The USA and India. Industrial Marketing Management, 43, 769-776.

Whang, Y.-O., Allen, J., Sahoury, N., \& Zhang, H. (2004). Falling in love with a product: The structure of a romantic consumer- product relationship. Advances in Consumer Research, 31, 320-327.

Yasin, N. M., Noor, M. N., \& Mohammad, O. (2012). Does image of country-of-origin matter to brand equity? Journal of Product and Brand Mangement, 16(1), 38-48.

Yeh, C.-H., Chen, C.-I., \& Sher, P. (2010). Investigation on perceived country image of imported food. Food Quality and Preference, 849856. 